\title{
Disegno ambiguo e sagace
}

\author{
Michele Valentino
}

\section{Abstract}

Il contributo affronta il rapporto fra conoscenza razionale e intuitiva. A tal proposito si fa riferimento alle qualità della mètis, come I'astuzia', la 'razionalità' 'flessibile' e l'ambiguità'. Le ultime due qualità, attraverso la messa in discussione del valore assoluto dell'intelligenza razionale, consentono una rivalutazione dell'intelligenza intuitiva affrontata in relazione al disegno e alle sue dimensioni. L'ambiguità del disegno viene percorsa, così come suggerisce l'etimo della parola, da ambo le direzioni, dalla parte di chi designa e dall'altra di chi legge. Un'ambilogia che permette di indagare la realtà senza definirla. La razionalità flessibile, attraverso la sagacia, permette al disegno e allo schizzo di essere riletto come strumento e luogo del progetto, che gli permette di essere considerato come sonda conoscitiva e non prescrittiva della realtà. All'interno dell'articolo, queste qualità vengono riviste attraverso l'ausilio di alcuni casi esemplificativi che fanno emergere il carattere intuitivo del disegno. Lo scopo è ridare valore alla conoscenza intelligibile e sensibile attuata tramite il disegno che consiste nella capacità di farsi partecipe dell'ambiguità e del potenziale del reale.
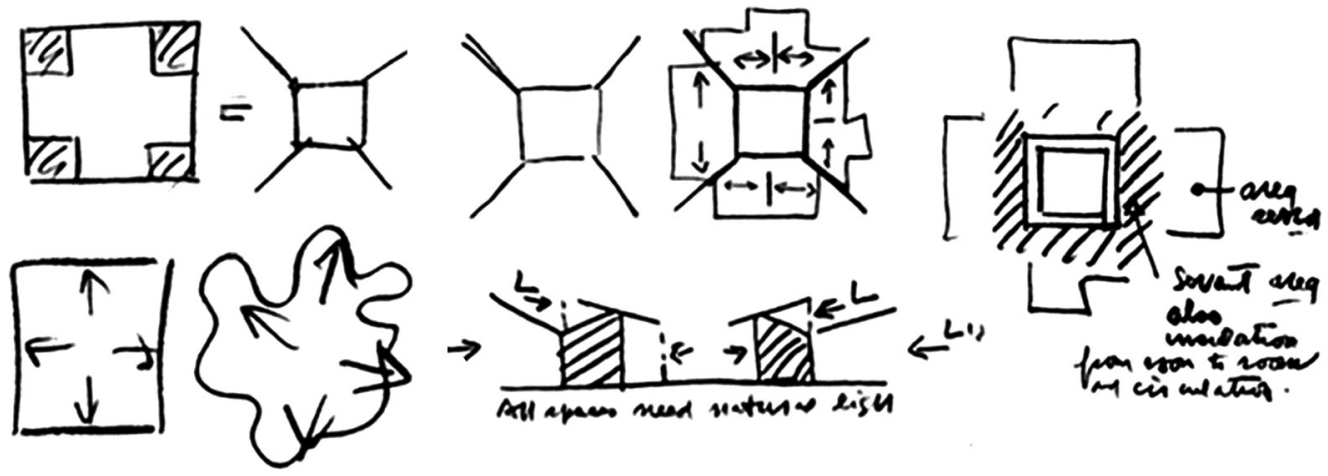


\section{Conoscenza intelligibile e sensibile}

Spesso si è portati a pensare in maniera oppositiva la conoscenza intuitiva dalla quella della ragione. Quest'ultima, considerata come la capacità umana di discernere il vero dal falso e stabilire le giuste sequenze del pensiero, si oppone alla prima che è determinata dall'immediato, non mediata da nessuna conoscenza acquisita. È dai tempi di Aristotele che questa contrapposizione è in atto, solo il processo razionale è considerato conoscitivo. La conoscenza sensibile, legata all'uso della facoltà dell'immaginazione è comprovata solo dalla fase in cui interviene l'intelletto attivo.

Come sostiene Edgar Morin, in un'intervista del 201 I, "Questa visione riduttiva e semplicistica della razionalità è all'origine dell'odierna dittatura del calcolo, che il razionalismo occidentale considera una condizione necessaria e sufficiente per dominare la realtà, dimenticando che molti degli aspetti essenziali della nostra vita [...] sfuggono del tutto ad ogni logica quantitativa" [Morin 20 I I] [ I]. Dagli illuministi in poi, la ragione diventa il dispositivo principale per la filosofia, facendosi guida in tutti i campi del sapere e della conoscenza.

La razionalità con il tempo è diventata l'unica facoltà su cui fare affidamento per la spiegazione del reale. La ragione si oppone all'istinto, diventando spesso il fondamento per l'uomo in tutti i campi nei quali interviene. László Mérö afferma, nel suo libro I limiti della razionalità. Intuizione, logica e trance-logica, che "nella cultura occidentale, una forma puramente razionale dell'intelligenza, basata sulla logica, ha conquistato un ruolo dominante [...] questo tipo di pensiero [...] ha senza dubbio dimostrato la sua ragion d'essere e la sua potenza" [Mérö 2005, p. 8] ma evidente che esistono diverse forme di conoscenza.

È importante ricordare come per gli stessi greci ci fossero due termini ben distinti per definire altrettante modalità della conoscenza. Da una parte quella intelligibile l'epistéme ( $\dot{\pi} \pi \iota \tau t \eta ́ \mu \eta$, ciò che sta sopra), dall'altra in maniera contrapposta a quella sensibile la dóxa ( $\delta o ́ \varepsilon ́ \alpha$, opinione). L'epistéme corrispondeva all'aspetto disciplinato e teorico della conoscenza, la dóxa designava la conoscenza che non possiede la certezza imparziale della verità, poiché basata sull'opinione soggettiva. Su questa separazione, e sulla prevalenza della prima sulla seconda, si basa il concetto di conoscenza a cui anche noi facciamo riferimento.

Mettendo in discussione questo concetto, Marcel Detienne e Jean Pierre Vernant, nel loro libro Le astuzie dell'intelligenza nell'antica Grecia, fanno emergere, in riferimento al mito di Meti, il ruolo della mètis come l'astuzia dell'intelligenza e come una modalità differente per conoscere le cose. I due autori inseriscono questa fase intermedia di conoscenza come una forma particolare capace di muoversi fra lo spirito apollineo, con il suo fattore razionale, e la mitologia greca, con la sua componente irrazionale. La mètis, costruendo pensieri figurativi, è capace di muoversi fra le categorie di pensiero garantendo la buona riuscita in differenti campi pratici dell'azione umana, dalla arte militare ai mestieri artigianali. Un'intelligenza pratica che nel suo esercizio non si preoccupa di descrivere il modo di procedere, ma confida nella dimensione sensibile del divenire e del molteplice. Detienne e Vernant fanno emergere tre manifestazioni basilari della mètis attraverso l'uso esemplificativo dell'episodio della gara dei carri narrato nel XXIII Canto dell'lliade di Omero, in cui Antiloco riesce a vincere attraverso l'astuzia e con l'ausilio dei consigli del padre Nestore, che godeva della fama di uomo saggio ed esperto nell'utilizzo della mètis. La prima qualità fa riferimento all'astuzia', in uno scontro ci può si imporre tramite la forza o, appunto, attraverso la mètis come manifestazione dell'astuzia. II secondo riguarda l'orizzonte temporale della razionalità flessibile'. La mètis, in questo caso, si muove fra passato, in quanto possiede scaltrezza acquisita nel tempo, presente, perché attenta a cogliere il momento opportuno in maniera vigile, e futuro, poiché possiede la capacità di progettarlo. In ultimo, la mètis allude all'ambiguità del reale, il trionfo su una realtà oscillante si ottiene non attraverso regole prestabilite, ma coltivando una maggiore trasformazione e trasfigurazione rendendosi complici di questo tipo di realtà. Se si prendono in considerazione le ultime due qualità della mètis descritte da Detienne e Vernant, appare evidente il parallelismo possibile fra queste e le peculiarità del disegno. 
Fig. I. Giovan Battista Piranesi, Carceri di Invenzione acquaforte (1745-1750).

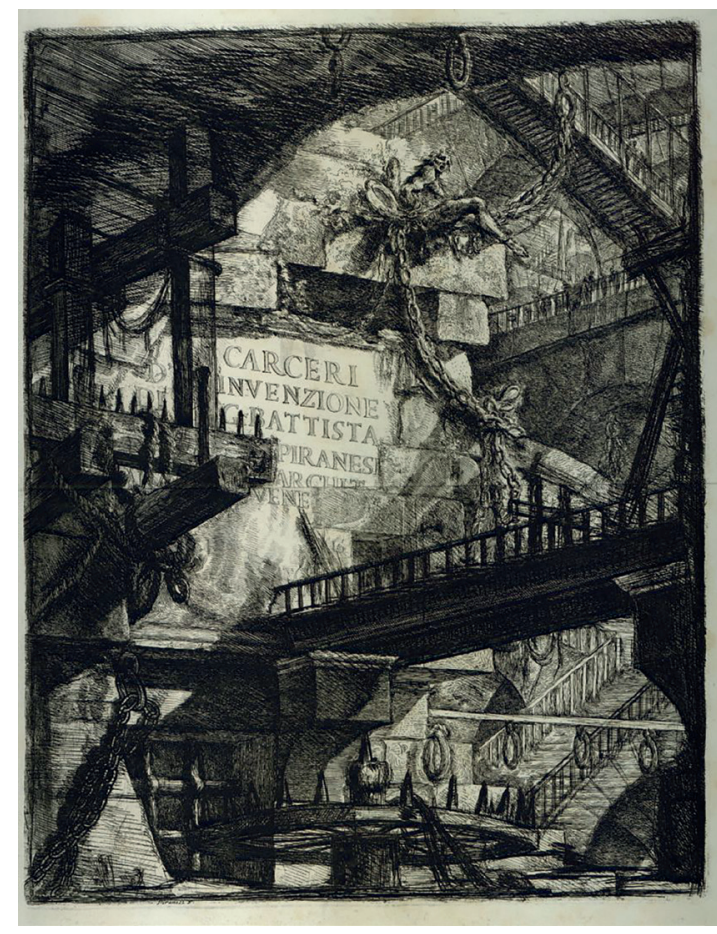

\section{Disegno e Ambiguità}

Come si è detto in precedenza, nel pensiero occidentale, l'uso di connotare l'ambiguità in senso negativo è ascrivibile al pensiero che riconduce la conoscenza a un principio che contrappone il vero e il falso. In quest'ottica, conoscenza e ambiguità portano a una dicotomia antitetica e conflittuale fra i due termini, poiché la razionalità non sostiene ciò che non si lascia esattamente circoscrivere.

Nella storia delle immagini l'uso dell'ambiguità è stato indagato con forza a partire dal '700, quando Giovan Battista Piranesi ha elaborato la serie Carceri di Invenzione (1745- I750) costruendo a partire dalla prospettiva degli spazi romani, luoghi in cui il movimento, a differenza della prospettiva rinascimentali che centralizzava l'immagine, portavano l'osservatore fuori dai confini della rappresentazione. William Hogarth, nel quadro Falsa Prosettiva, porta, in un gioco di illusioni ottiche, l'osservatore a indagare l'ambiguità dello strumento percettivo. È stato Ernst H. Gombrich a indagare in maniera profonda il tema delle ambiguità percettive nel libro Arte e illusione: studio sulla psicologia della rappresentazione pittorica (1965). L'autore sostiene che "L'incisione dell'olandese M. C. Escher offre un istruttivo contrappeso a quella di Hogarth, proprio perché in essa la prospettiva appare così corretta. Solo quando l'osserviamo più da vicino ci accorgiamo che una simile struttura non può esistere nel nostro mondo e che l'artista vuole trasportarci nei regni assurdi in cui termini come 'su' e 'giù', 'destra' e 'sinistra' hanno perduto il loro significato. L'incisione è una meditazione dell'artista sullo spazio, ma è anche una dimostrazione della parte che vi ha l'osservatore: nel tentativo di individuare il rapporto voluto dall'artista tra le cose e i punti di vista ci rendiamo contro dei paradossi del suo ordinamento" [Gombrich 1965, p. 295].

La rappresentazione, in questi casi, non adempie al compito di rapidità comunicativa o di chiarezza interpretativa, ma può tendere volontariamente all'ambiguità percettiva. Nella lettura e nell'osservazione di un'immagine, quindi, è possibile disvelare qualcosa che in origine in essa era solo sottesa e che allo stesso tempo, come nella poesia, può esprimere ambiguità [Empson 1965]. Un'ambiguità che permette di essere percorsa, così come suggerisce l'etimo della parola stessa, da ambo le direzioni, da una parte chi designa e dall'altra chi legge. Un'ambilogia, cioè un discorso incerto, che indaga senza definire. 
Nella raffigurazione dello spazio I"ambiguità dell'immagine' può essere definita come "la proprietà dell'immagine di essere contemporaneamente sé stessa e l'oggetto rappresentato, di essere cioè un supporto materico recante segni bidimensionali e di evocare al tempo stesso lo spazio profondo, tridimensionale, infinito che quei segni trasmettono" [Gregory 1986, p. 21].

Allo stesso modo, anche se con presupposti differenti, lo schizzo in architettura permette di aprire spazi interpretativi che esulano dalla necessità descrittiva o prescrittiva del progetto. L'ambiguità rappresentativa dello schizzo favorisce le associazioni di idee non prossime, permettendo l'indagine e la scoperta degli intervalli nascosti e mostrando puramente le fasi indagatrici. Una ricerca del campo del possibile e del potenziale, di ciò che in potenza potrebbe essere. Questo ci riconduce al pensiero di Luis I. Kahn quando interroga il tema dell'abitare per una casa non realizzata, la Goldenberg House in Pennsylvania del 1959. In questa occasione elabora una serie di schizzi-diagrammi dove rileva le forze che possono agire sulla forma. In essi non sono contenute le informazioni della prefigurazione dell'architettura, ma permettono l'indagine delle possibilità configurative. L'architetto descrivendo il progetto con gli schizzi, in un'intervista del 196 I sostiene che si comincia da un limite "ma talvolta l'interno vuole estendersi all'esterno e prorompere oltre i muri" [Norberg-Schulz 1980, p. 79] [2]. II pensiero progettuale viene indagato attraverso le forze diagonali dello spazio che non possono prefigurarsi in modo prescrittivo, ma necessitano della ambiguità del disegno per essere indagate e, di volta in volta, specificate e chiarite.

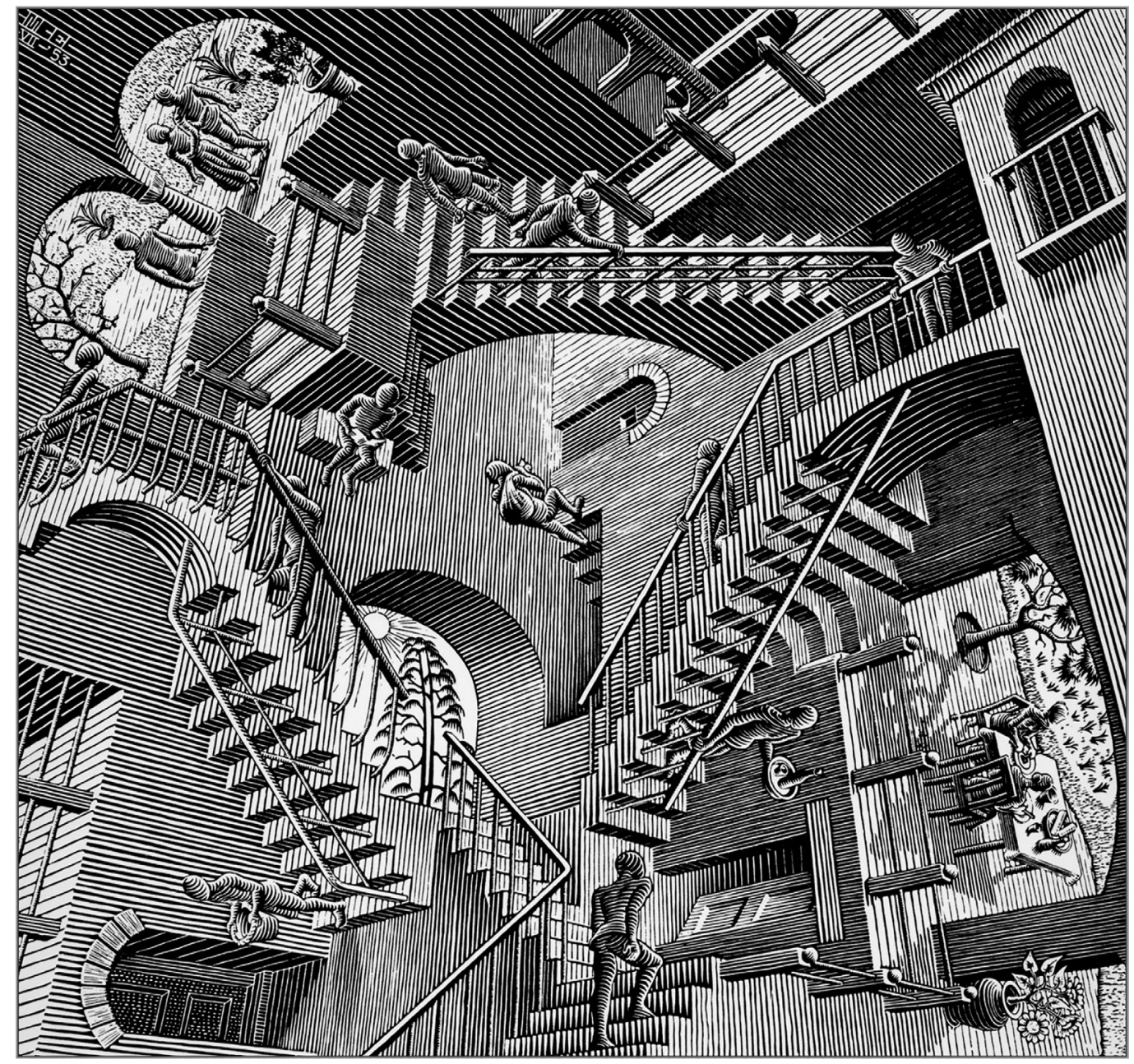




\section{Disegno e Sagacia}

La sagacia, in quanto capacità di capire e risolvere situazioni, può essere agevolmente associata alla qualità naturale dell'intelligenza intuitiva del disegno. In questo senso, il disegno, come strumento e luogo del progetto, non può che essere considerato come sonda conoscitiva [Maciocco, Tagliagambe 1997].

Se si considera l'orizzonte temporale dello schizzo, e in più in generale del disegno, appare l'abilità di questo di muoversi fra le dimensioni temporali del passato, del presente e del futuro.

A tal proposito appare esemplare il caso degli schizzi del Padiglione Barcellona del 1929 ad opera dell'architetto tedesco Ludwig Mies van der Rohe. Due schizzi in sequenza mostrano l'intuizione e il fiuto dell'architetto nell'individuare l'impianto complesso del padiglione. Nel primo emergono due forme concluse ed elementari collegate da un muro, nel secondo appare evidente quello che sarà il disegno quasi definitivo del padiglione, decretato da lastre di derivazione De Stijl che creano molteplici prospettive, in quanto le lastre stesse non sono mai connesse fra loro. Un segno doppio rimarca nel terminale della pianta l'idea di recinto che, nel progetto conclusivo, definirà la seconda vasca interna dove verrà posizionata la statua di Georg Kolbe. Colpisce che Mies van der Rohe, nei suoi schizzi, lavori in pianta in quanto considerata generatrice del progetto. I problemi della pendenza del suolo lo porteranno ad elaborare un basamento in travertino simbolo di una connessione culturale con la romanità. Di fatto, questo basamento ha origini profonde nel pensiero dell'architetto e perdurerà in tutta la sua produzione. Dobbiamo fare un passo indietro per ricordare il progetto di un concorso per un monumento a Bismarck, Elisenhöhe Bingen del 1910 , dove, in un prospetto realizzato con grande cura, il progettista elabora un profondo basamento che permette il posizionamento di un impianto ad esedra contenente la statua del cancelliere. Come ricorda Jean-Louis Cohen [Cohen 1994], l'apprendistato presso lo studio di Peter Behrens gli consentirà di conoscere il lavoro di Karl Friedrich Schinkel e
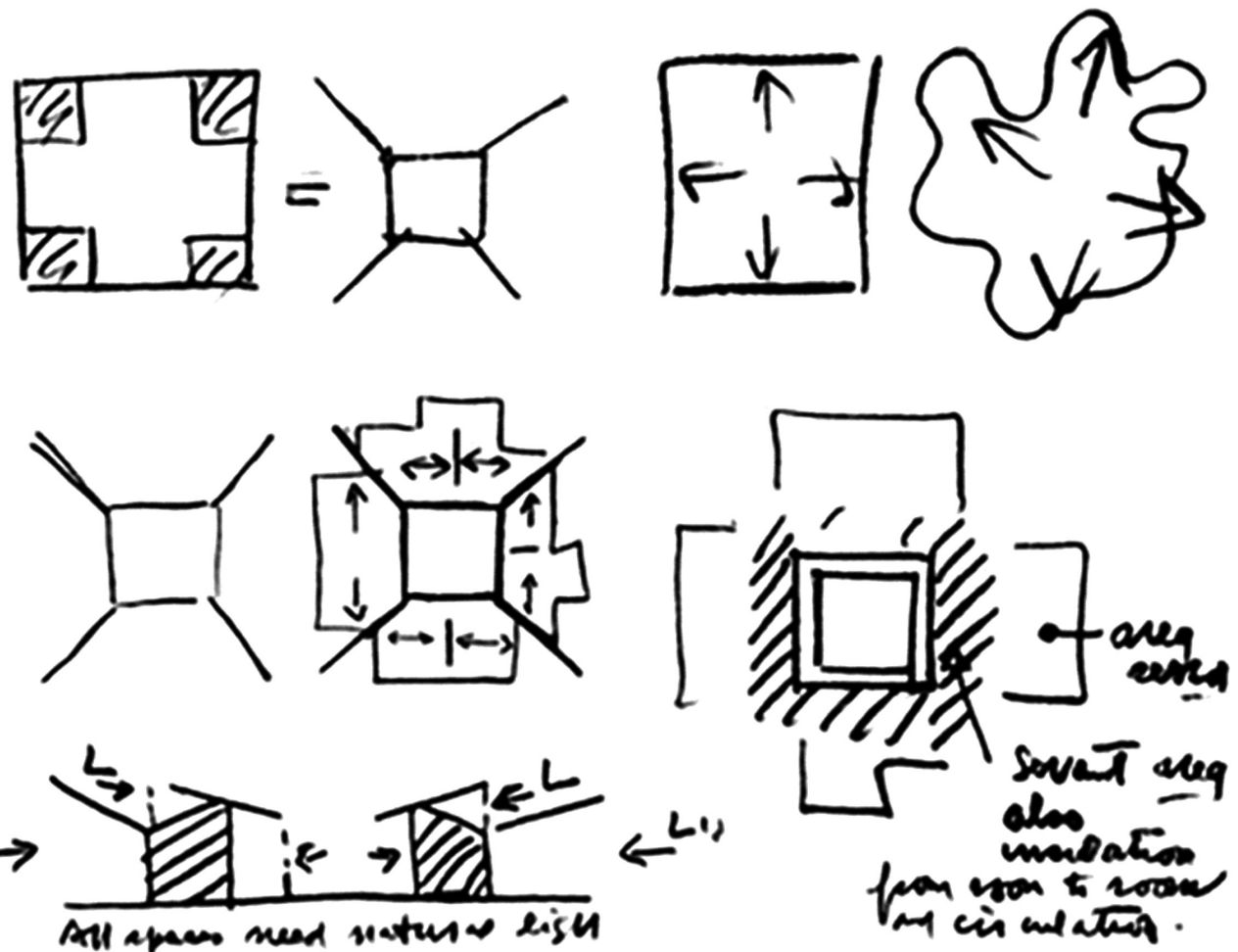
specificatamente il progetto del 1834 per il palazzo reale sull'Acropoli di Atene, disegnato per Ottone I Wittelsbach re di Grecia, e il progetto del I 838 per il palazzo estivo per lo zar ad Orianda, in Crimea. In entrambi i disegni, di pregevole fattura, Schinkel evidenzia il monte sacro dell'Acropoli e quello naturale in Crimea. Sono basamenti profondi che indicano non una lastra quanto un ancoraggio come parte della montagna stessa. Da queste conoscenze storiche comprendiamo che il basamento del Padiglione è realizzato in travertino proprio per rammemorare la dimensione antica e profonda del basamento che si rivolge ai luoghi sacri della classicità. Mies nei suoi schizzi opera una rottura di senso con il proprio tempo, da un lato recupera le avanguardie del Neoplasticismo olandese e dall'altro le matrici più antiche della classicità.

Se guardiamo il potere dell'intelligenza flessibile di prefigurare gli sviluppi futuri, non possiamo non rivolgere la nostra attenzione ai lavori di Giovanni Michelucci. I suoi disegni sono densi e mostrano intelaiature e cavità, in quanto era per lui indispensabile indagare i luoghi dell'abitare. In questa direzione sono esemplari i disegni per la ristrutturazione del quartiere Santa Croce a Firenze (1967-1968) ed Elementi di città (1968), dove elabora un'alternativa progettuale in seguito all'inondazione dell'Arno a Firenze.

Se per Mies lo schizzo era planare, per Michelucci è sempre prospettico e relazionare del contesto urbano o territoriale. Era un modo per affermare che lo spazio della città e del territorio dovesse essere letto da un soggetto che attraversava i luoghi. Per capire la forza premonitrice dei disegni di Michelucci, dobbiamo menzionare il progetto per il Centro sperimentale del marmo a Carrara. Dai diversi schizzi elaborati in occasione della commemorazione del quinto centenario della nascita di Michelangelo, che si sarebbe celebrato nel I975, l'architetto ci consegna dei disegni in cui lo spazio è generato da azioni telluriche, creste che si sollevano e determinano gli spazi dei laboratori. Si comprende come Michelucci avesse elaborato un'inscindibilità del legame fra natura e artificio, dove l'artificio si rendeva natura integrandosi all'interno di una di un'idea di terra madre.

In questi esempi appare evidente la capacità del disegno di possedere 'scaltrezza' come effetto di un'esperienza acquisita in un tempo passato, 'rapidità' come capacità di cogliere il momento opportuno (kairos) e previsione come attitudine di immaginare e progettare il futuro.

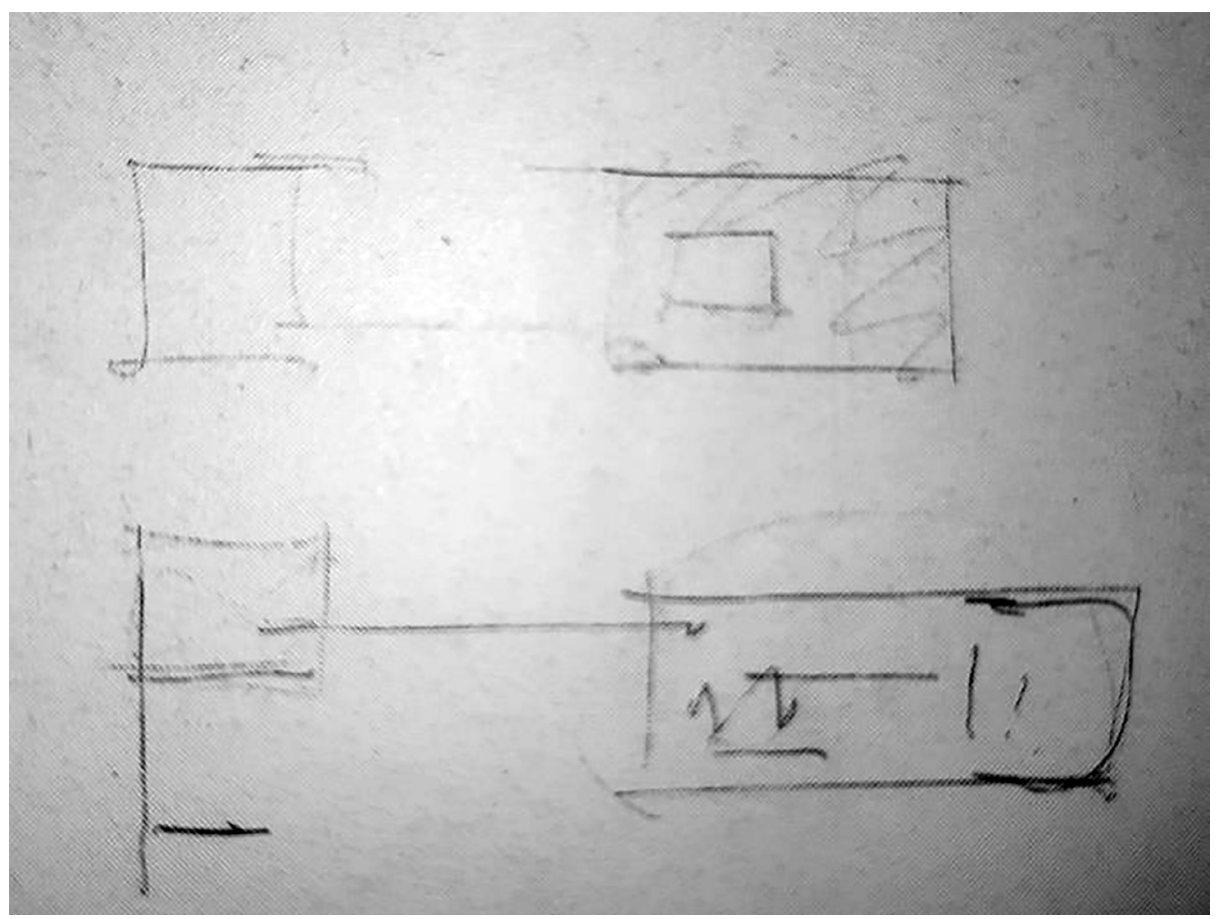




\section{Conclusioni}

I miti nella letteratura greca appaiono solo in forma di rapide allusioni, presupponendo che tutti li conoscano, non vengono mai esposti integramente. Non occorre meravigliarsi se lo stesso mito sia stato interpretato in maniera dissimile, in quanto non esiste una teoria univoca per tutti i miti, che possono possedere differenti intenzioni o diversi livelli di significato. Per questo, il tentativo interpretativo del mito di Meti da parte di Detienne e Vernant ci permette di costruire parallelismi tra il significato attribuito alle abilità della dea e quelle del disegno.

La messa in discussione del valore assoluto dell'intelligenza razionale consente una rivalutazione dell'intelligenza intuitiva. Nel suo libro The Metaphoric Mind, Bob Samples ci ricorda che:"Albert Einstein ha definito la mente intuitiva o metaforica un dono sacro. Ha aggiunto che la mente razionale era un fedele servitore. Ė paradossale che nel contesto della vita moderna abbiamo hanno iniziato a adorare il servo e profanare il divino" [Samples 1976, p. 26]. - Allo stesso modo, la capacità descrittiva e prescrittiva del disegno come qualità unica e privilegiata ha predominato nella nostra società, mentre, l'indagine delle caratteristiche di ambiguità e di sagacia del disegno, che ci permettono di muoverci nella lettura di realtà oscillanti, non governabili solo tramite regole prefissate o prescrizioni date, è stata altamente trascurata.

II segreto del disegno, se associato alle qualità descritte della mètis, consiste nella sua capacità di farsi partecipe dell'ambiguità e del potenziale del reale come illustrato nei casi sopra esposti.

Fig. 5. Giovanni Michelucci, Centro sperimentale del marmo a Carrara, schizzo di progetto (1965).

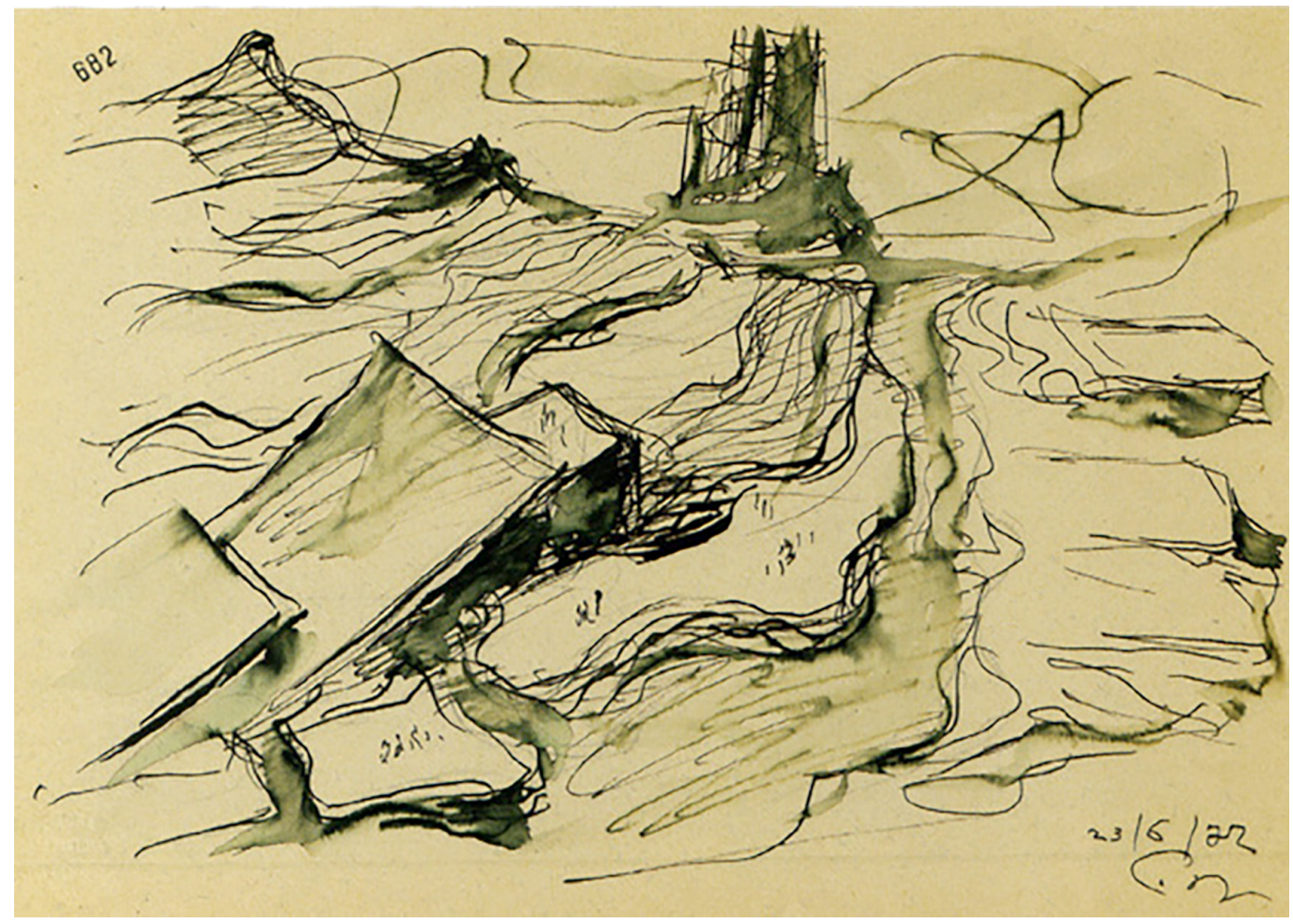

Note

[l] Edgar Morin 20 II, Puntate sul quoziente emotivo: Repubblica del 2 aprile 201 I https://ricerca.repubblica.it/repubblica/ archivio/repubblica/20 I I/04/02/puntate-sul-quoziente- emotivo.076.html

[2] La prima versione dell'intervista è stata pubblicata in Perspecta, 7 del 196I, pp. 9-28, ed è stata raccolta nel libro di Christian Norberg Schulz, Louis I. Kahn. Idea e immagine. 


\section{Riferimenti bibliografici}

Cohen Jean-Louis, (1994). Ludwig Mies van der Rohe. Roma-Bari: Laterza.

Detienne Marcel,Vernant Jean-Pierre (1978). Le astuzie dell'intelligenza nell'antica Grecia. Roma-Bari: Laterza.

Empson William (1965). Sette tipi di ambiguità. Torino: Einaudi.

Gombrich Ernst H. (1965). Arte e illusione. Studio sulla psicologia della rappresentazione pittorica.Torino: Einaudi.

Gregory Richard (1986). L'occhio confuso. In XY dimensioni del disegno, n. I, pp. 19-20. Roma: Cedis Editrice.

Norberg-Schulz Chistian (1980) Louis I. Kahn. Idea e immagine. Roma: Officina Edizioni.

Maciocco Giovanni,Tagliagambe Silvano (1997). La città possibile: territorialità e comunicazione nel progetto urbano. Bari: Dedalo Mérö László (2005). I limiti della razionalità. Intuizione, logica e trance-logica. Bari: Dedalo.

Morin Edgar (20 I I, Aprile 2), Puntate sul quoziente emotivo. In: Repubblica. Estratto da: https://ricerca.repubblica.it/repubblica/ archivio/repubblica/20 I I/04/02/puntate-sul-quoziente- emotivo.076.html.

Samples Bob (1976). The metaphoric mind: A celebration of creative consciousness. Boston: Addison Wesley Publishing Company.

Autore

Michele Valentino, Università degli Studi di Sassari, mvalentino@uniss.it

Per citare questo capitolo:Valentino Michele (2020). Disegno ambiguo e sagace/Ambigous and sagace drawing. In Arena A., Arena M., Brandolino R.G., Colistra D., Ginex G., Mediati D., Nucifora S., Raffa P. (a cura di). Connettere. Un disegno per annodare e tessere. Atti del $42^{\circ}$ Convegno Internazionale dei Docenti delle Discipline della Rappresentazione/Connecting. Drawing for weaving relationships. Proceedings of the 42th International Conference of Representation Disciplines Teachers. Milano: FrancoAngeli, pp. |434- 1449. 


\title{
Ambigous and Sagace Drawing
}

\author{
Michele Valentino
}

\section{Abstract}

The contribution addresses the relationship between rational and intuitive knowledge. In this regard reference made to the qualities of the mètis, such as cunning, 'flexible', 'rationality' and 'ambiguity'. The last two qualities -through the questioning of rational intelligence absolute value- allow a reassessment of the intuitive intelligence faced concerning the design and its dimensions. Drawing's ambiguity is traversed -as etymology suggests- by both directions -from those who designate and other of the reader. An ambiguity that allows us to investigate reality without defining it. Flexible rationality, through sagacity, allows the drawing and sketch to be reinterpreted as a tool and place of the project, which allows it to be considered as a cognitive and non-prescriptive probe of reality. Inside the issue, these qualities are review through the help of some example cases that bring out the drawing intuitive character. The aim is to restore value to the intelligible and sensitive knowledge implemented through the design, which consists of the ability to participate in the ambiguity and potential of reality.

\section{Keywords}
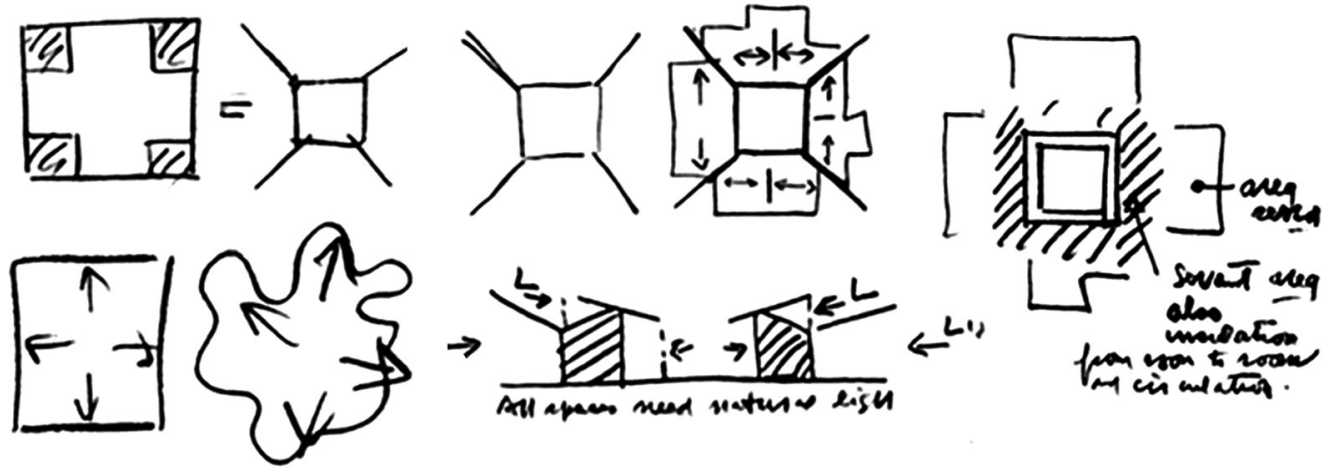


\section{Intelligible and sensitive knowledge}

Often, we tend to think in an oppositional intuitive knowledge from that of reason. The latter, considered as the human ability to discern the true from the false and establish the right sequences of thought, opposes the first that is determined by the immediate, not mediated by any knowledge acquired. It is from Aristotle's times that this opposition has been taking place; only the rational process is considered cognitive. Sensitive knowledge, linked to the use of the faculty of imagination, is only proven by the phase in which the active intellect intervenes.

As Edgar Morin argues, in an interview in 201 I, "This reductive and simplistic view of rationality is at the origin of today's dictatorship of calculation, which Western rationalism considers a necessary and sufficient condition to dominate reality, forgetting that many of the essential aspects of our life [...] completely escape any quantitative logic" [Morin 20 I I] [I]. From the Enlightenment onwards, reason becomes the primary device for philosophy, guiding itself in all fields of knowledge and knowledge.

Rationality over time has become the only faculty on which to rely for the explanation of reality. Reason opposes instinct, often becoming the foundation for man in all the fields in which he intervenes. László Mérö states, in his book I limiti della razionalità. Intuizione, logica e trance-logica, which "In Western culture, a purely rational form of intelligence, based on logic, has conquered a dominant role. [...] this type of thinking [...] has undoubtedly demonstrated its reason for being and its power" [Mérö 2005, p. 8], but it is clear that there are different forms of knowledge.

It is important to remember that for the Greeks themselves, there were two very distinct terms to define as many modalities of knowledge. On the one hand, the intelligible epistéme

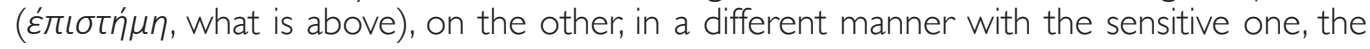

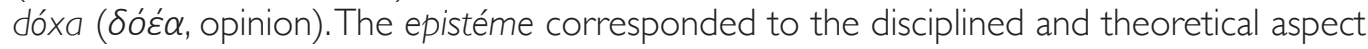
of knowledge, the dóxa designated knowledge that does not possess the impartial certainty of truth since it based on subjective opinion. Upon this separation -and prevalence of first over latter- is based knowledge concept, which we also do reference.

By questioning this concept, Marcel Detienne and Jean Pierre Vernant, in their book Le astuzie dellintelligenza nell'antica Grecia, bring out, concerning the myth of Meti, the role of the mètis as the cunning of intelligence and as a different way to know things. The two authors insert this intermediate phase of knowledge as a particular form capable of moving between the Apollonian spirit, with its rational factor, and Greek mythology, with its irrational component. The mètis, building figurative thoughts, can move between the categories of thought, guaranteeing success in different practical fields of human action, from military art to crafts. Practical intelligence that in its exercise, does not bother to describe the way to proceed but relies on the sensitive dimension of becoming and the multiple. Detienne and Vernant bring out three primary manifestations of the mètis through the exemplary use of the episode of the chariot race narrated in the Homer's XXIII Canto of the lliad, in which Antiloco manages to win through cunning and with the help of the advice of the father, Nestor. He enjoyed the fame of a wise and expert man in the use of mètis. The first quality refers to cunning, in a clash, it can be imposed by force or, precisely, through mètis as a manifestation of cunning. The second concerns the time horizon of flexible rationality. The mètis, in this case, moves between the past, in that it possesses shrewdness acquired over time, present, because it is careful to seize the opportune moment in a vigilant way, and future since it possesses the ability to plan it. Lastly, the mètis alludes to the ambiguity of reality, the triumph over an oscillating reality is achieved not through pre-established rules, but by cultivating a more significant transformation and transfiguration by becoming accomplices of this type of reality.

If we take into consideration the last two qualities of the mètis described by Detienne and Vernant, the possible parallelism between these and the peculiarities of the design is evident. 


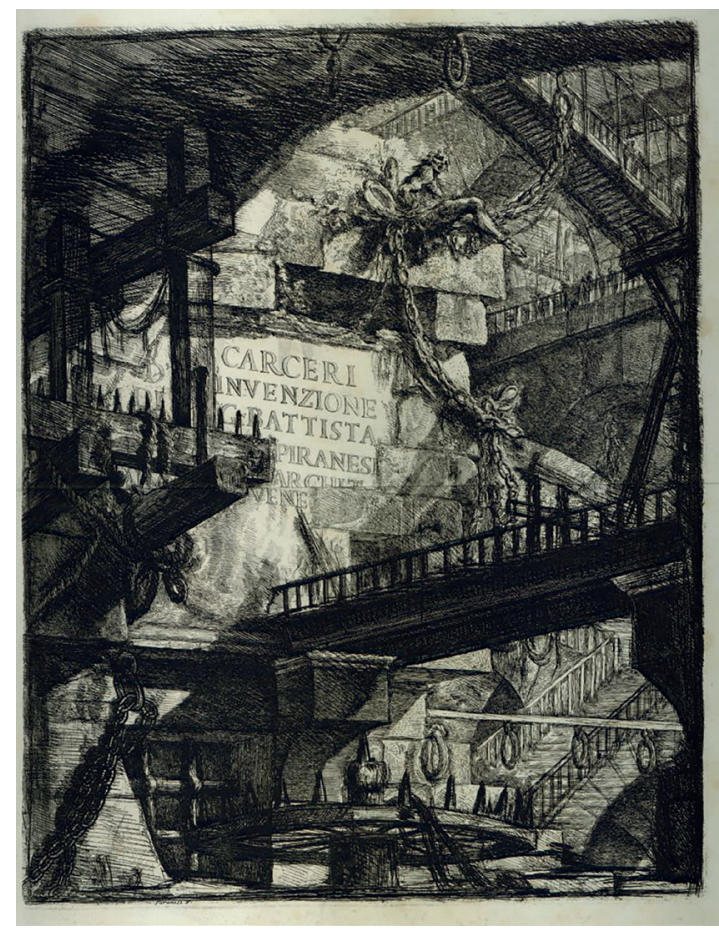

\section{Drawing and Ambiguity}

As previously mentioned, in Western thought, the use of connoting ambiguity in a negative sense is attributable to thinking that leads knowledge back to a principle that contrasts truth and falsehood. In this perspective, knowledge and ambiguity lead to an antithetical and conflicting dichotomy between the two terms, since rationality does not support what cannot be precisely circumscribed.

In the history of images, the use of ambiguity has been actively investigated since the 18th century, when Giovan Battista Piranesi developed the Carceri di Invenzione series (I7451750), building from the perspective of Roman spaces, places where the movement, unlike the Renaissance perspective that centralized the image, took the viewer beyond the confines of representation. William Hogarth, in the False Prosecutive framework, leads, in a game of optical illusions, the observer to investigate the ambiguity of the perceptive tool.

It was Ernst H. Gombrich who deeply investigated the theme of perceptual ambiguities in the book Arte e illusione: studio sulla psicologia della rappresentazione pittorica (1965). The author claims that "The engraving by the Dutchman M. C. Escher offers an instructive counterweight to that of Hogarth, precisely because the perspective appears so correct in it. Only when we look at it more closely, do we realize that such a structure cannot exist in our world and that the artist wants to transport us to the absurd realms where terms such as 'up' and 'down', 'right' and 'left' have lost their meaning. Engraving is artist's meditation on space, but it is also a demonstration of the part that the observer has in it: in an attempt to identify the relationship wanted by the artist between things and points of view we turn against the paradoxes of his sorting" [Gombrich 1965, p. 295].

The representation, in these cases, does not fulfil the task of communicative or interpretative clarity rapidity, but can voluntarily tend perceptual ambiguity. In reading and observing an image, therefore, it is possible to reveal something that was initially only underlying and that at the same time, as in poetry, can express ambiguity [Empson 1965]. An ambiguity that allows it to be covered, as suggested by word etymology, in both directions, on the one hand, those who designate and other readers. An ambilogy, that is, an uncertain speech, which investigates without defining. 
In the representation of space, the 'ambiguity of the image' can be defined as "the property of the image of being simultaneously itself and the object represented, that is, of being material support bearing two-dimensional signs and of evoking deep space at the same time, three-dimensional, infinite that those signs transmit" [Gregory 1986, p. 2 I].

In the same way, even if with different assumptions, the sketch in architecture allows to open interpretative spaces that go beyond the descriptive or prescriptive need of the project. The representative ambiguity of the sketch favours associations of ideas that are not forthcoming, allowing the investigation and discovery of hidden intervals and purely showing the investigative phases. It is a research for the field of the possible and of the potential, of what might be. This brings us back to the thought of Luis I. Kahn when he questions the theme of living for an unrealized house, the Goldenberg House in Pennsylvania of 1959. On this occasion, he elaborates a series of sketch-diagrams where he detects the forces that can act on the form. They do not contain the information of the prefiguration of the architecture but allow the investigation of the configuration possibilities. The architect, describing the project with the sketches, in an interview in 196I argues that it starts from a limit, "but sometimes the interior wants to extend outside and burst beyond the walls" [Norberg-Schulz 1980, p. 79] [2]. Design thinking investigated through the diagonal forces of space that cannot prefigure themselves in a prescriptive way but need the ambiguity of the design to be investigated and, from time to time, specified and clarified.

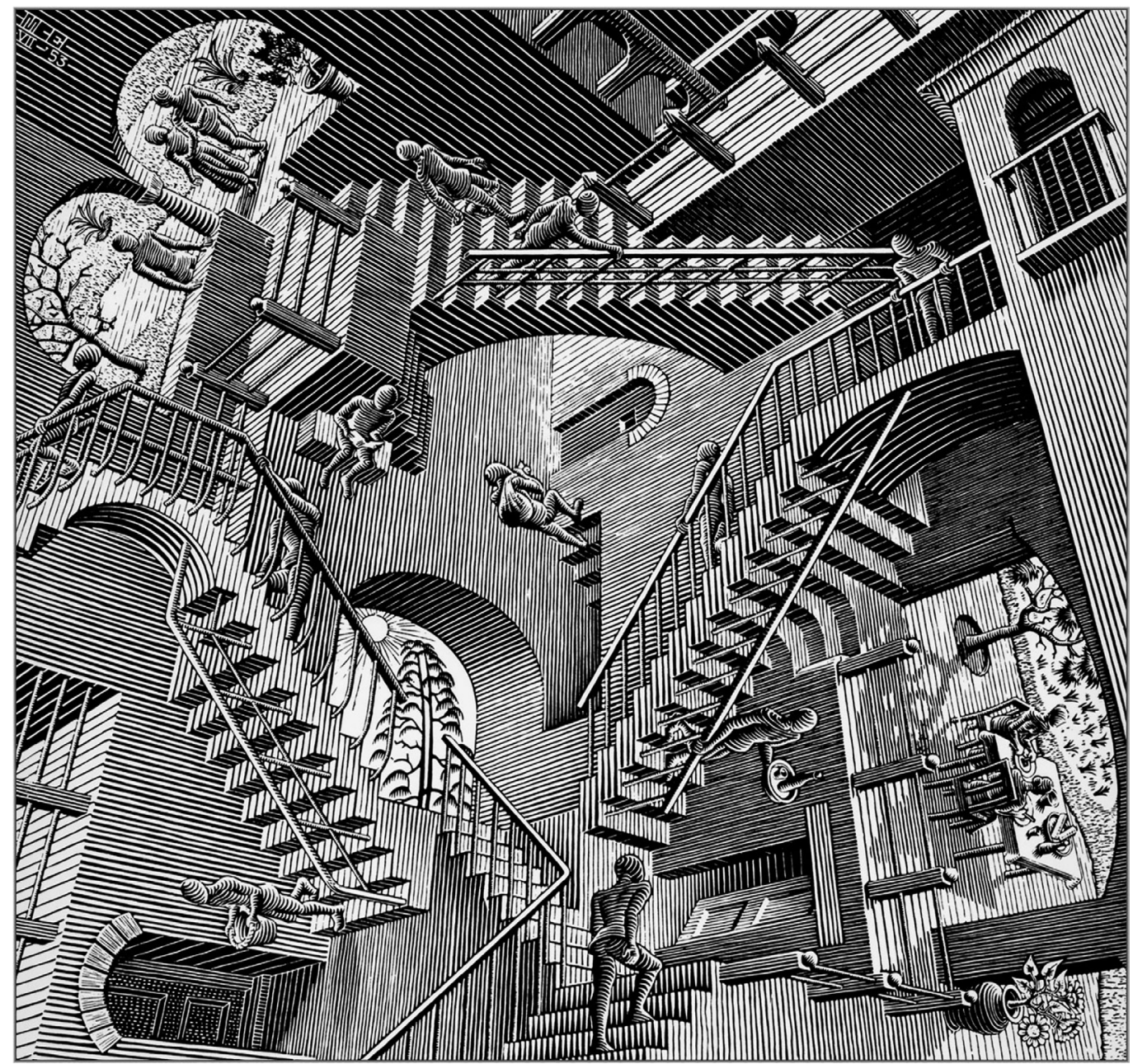




\section{Drawing and Sagsagacity}

The sagacity, as the ability to understand and solve situations, it can be easily associated with the inherent quality of the drawing as intuitive intelligence. In this sense, drawing, as an instrument and place of the design, can only be considered as a cognitive probe [Maciocco, Tagliagambe 1997].

If we consider sketch's temporal horizon, and more generally of the drawing, the ability of this to move between the temporal dimensions of the past, present and future appear.

In this regard, the case of the sketches of the Barcelona Pavilion of 1929 by the German architect Ludwig Mies van der Rohe is exemplary. Two sketches in sequence show the architect's intuition and flair in identifying the complex layout of the pavilion. In the first two finished and elementary forms emerge connected by a wall, in the second it appears evident what will be the almost final design of the pavilion, decreed by slabs of derivation De Stijl that create multiple perspectives, as the slabs themselves are never connect. A double sign highlights the idea of a fence in the terminal of the plant which, in the final project, will define the second internal tank where the statue of Georg Kolbe will be positioned. It is striking that Mies van der Rohe, in his sketches, works in the plan since he is considered the generator of the project. The problems of the slope of the ground will lead him to develop a travertine base symbol of a cultural connection with Roman times. This base has deep origins in the architect's thinking and will continue throughout its production. We must take a step back to remember the project for a competition for a monument to Bismarck, Elisenhöhe Bingen of 1910, where, in a prospect created with great care, the designer develops a deep base that allows the positioning of an exedra plant containing the statue of the chancellor. As Jean-Louis Cohen (1994) recalls, his apprenticeship at Peter Behrens' studio will allow him to learn about the work of Karl Friedrich Schinkel and specifically the I 834 project for the royal palace on the Acropolis of Athens, designed for Otto I Wittelsbach king of Greece, and the 1838 plan for the Tsar's summer palace in Orianda, Crimea. In both
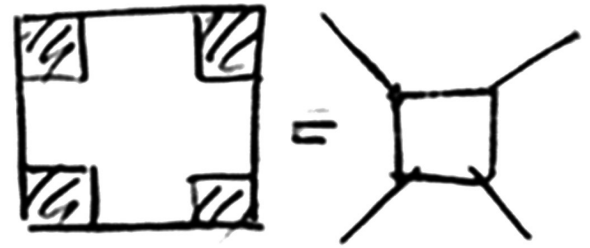

Fig. 3. Luis I. Kahn, drawing (1959).
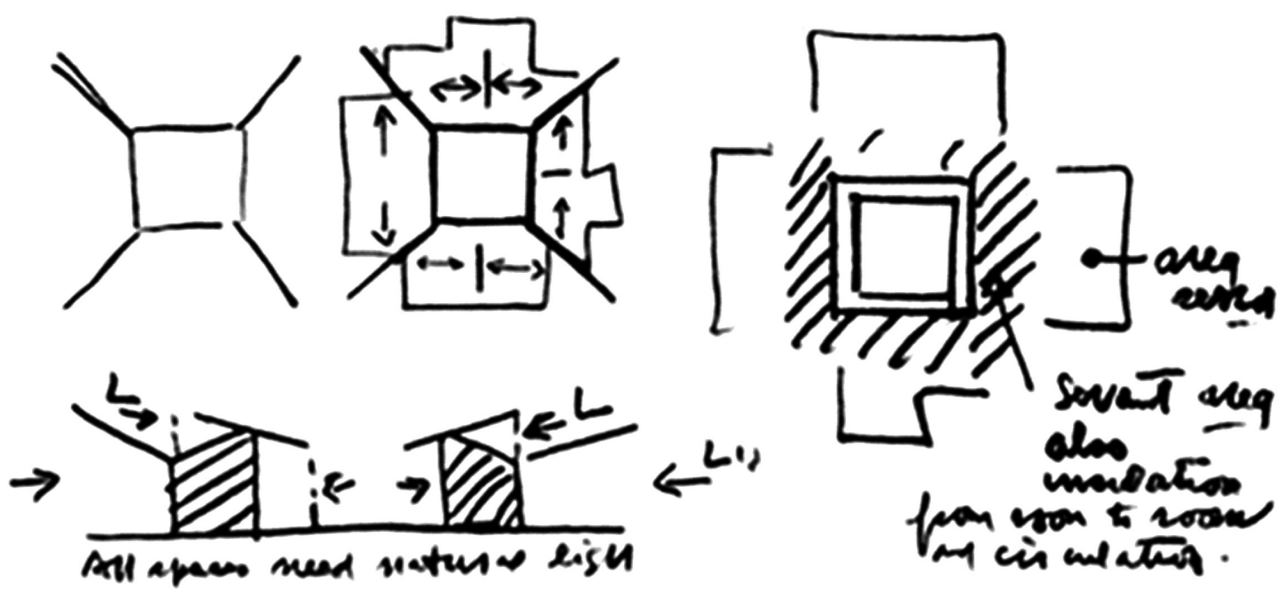
drawings, of exceptional artistry, Schinkel highlights the sacred mountain of the Acropolis and the natural one in Crimea. They are deep bases that indicate not a slab as much as an anchor as part of the mountain itself. From this historical knowledge, we understand that the base of the Pavilion is made of travertine to commemorate the ancient and profound dimension of the base that addresses the sacred places of classicism. Mies, in his sketches, makes a break in meaning with his time, on the one hand, he recovers the avant-garde of Dutch Neoplasticism and on the other the oldest matrices of classicism.

If we look at the power of flexible intelligence to prefigure future developments, we cannot fail to turn our attention to the works of Giovanni Michelucci. His designs are dense and show frames and cavities, as it was essential for him to investigate the places of living. In this direction, the drawings for the renovation of the Santa Croce district in Florence (19671968) and Elementi di città (1968) are exemplary, where he developed a design alternative following the flooding of the Arno in Florence.

If for Mies the sketch was planar, for Michelucci it is always a perspective and relationship of the urban or territorial context. It was a way of affirming that the space of the city and the territory should read by a subject who crossed places. To understand the premonitory force of Michelucci's drawings, we must mention the project for the Experimental Center of Marble in Carrara. From the various sketches elaborated on the occasion of the commemoration of the fifth centenary of Michelangelo's birth, which was to celebrate in 1975, the architect gives us drawings in which telluric actions generate space. These crests rise and determine the spaces of the laboratories. It can be understood how Michelucci had developed an inseparable link between nature and artifice, where artifice became nature by integrating itself into one of a mother earth idea.

In these examples, drawing ability to possess shrewdness as an effect of an experience acquired in a past time, speed as the ability to seize the opportune moment (kairos) and prediction as an attitude to imagine and plan the future, is evident.

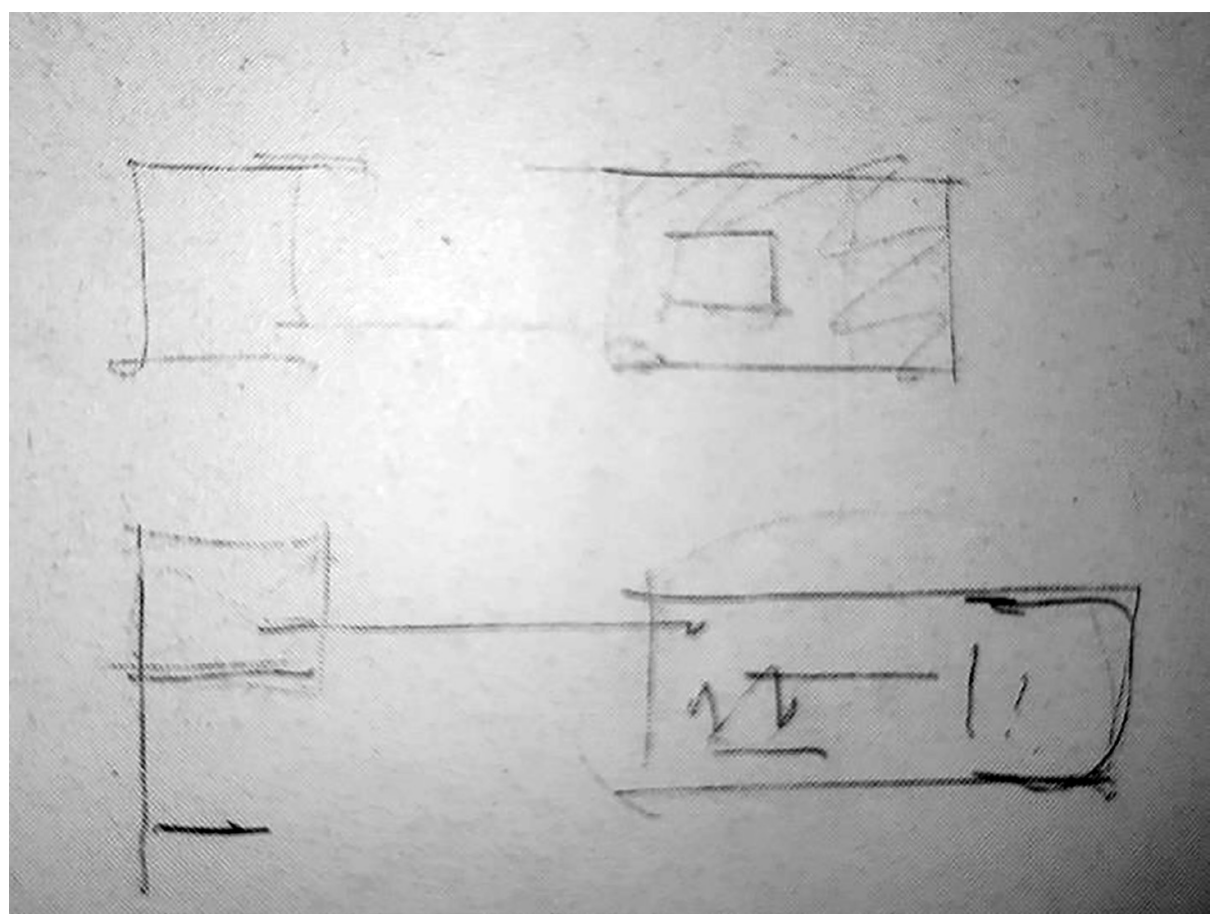




\section{Conclusions}

Myths in Greek literature appear only in the form of quick allusions, assuming that everyone knows them; they are never fully exposed. It is no wonder that the same myth has interpreted dissimilarly, as there is no one-size-fits-all theory, which may have different intentions or different levels of meaning. For this reason, Detienne and Vernant's attempt to interpret the myth of Meti allows us to build parallels between the meaning attributed to the skills of the goddess and those of drawing.

Questioning the absolute value of rational intelligence allows a reassessment of intuitive intelligence. In his book The Metaphoric Mind, Bob Samples reminds us that: "Albert Einstein called the intuitive or metaphoric mind a sacred gift. He added that the rational mind was a faithful servant. It is paradoxical that in the context of modern life we have begun to worship the servant and defile the divine "[Samples 1976, p. 26]. In the same way, the descriptive and prescriptive ability to draw as a unique and privileged quality has predominated in our society. At the same time, the investigation of the characteristics of ambiguity and sagacity of drawing, which allow us to move in the reading of oscillating, non-governable realities only through pre-established rules or given prescriptions, it has been highly neglected.

Drawing secret -associated with qualities described in the mètis- lies in its ability to participate in the ambiguity and potential of reality as illustrated in the cases above.

Fig. 5. Giovanni Michelucci, Experimental center of marble in Carrara, sketch drawing (1965)

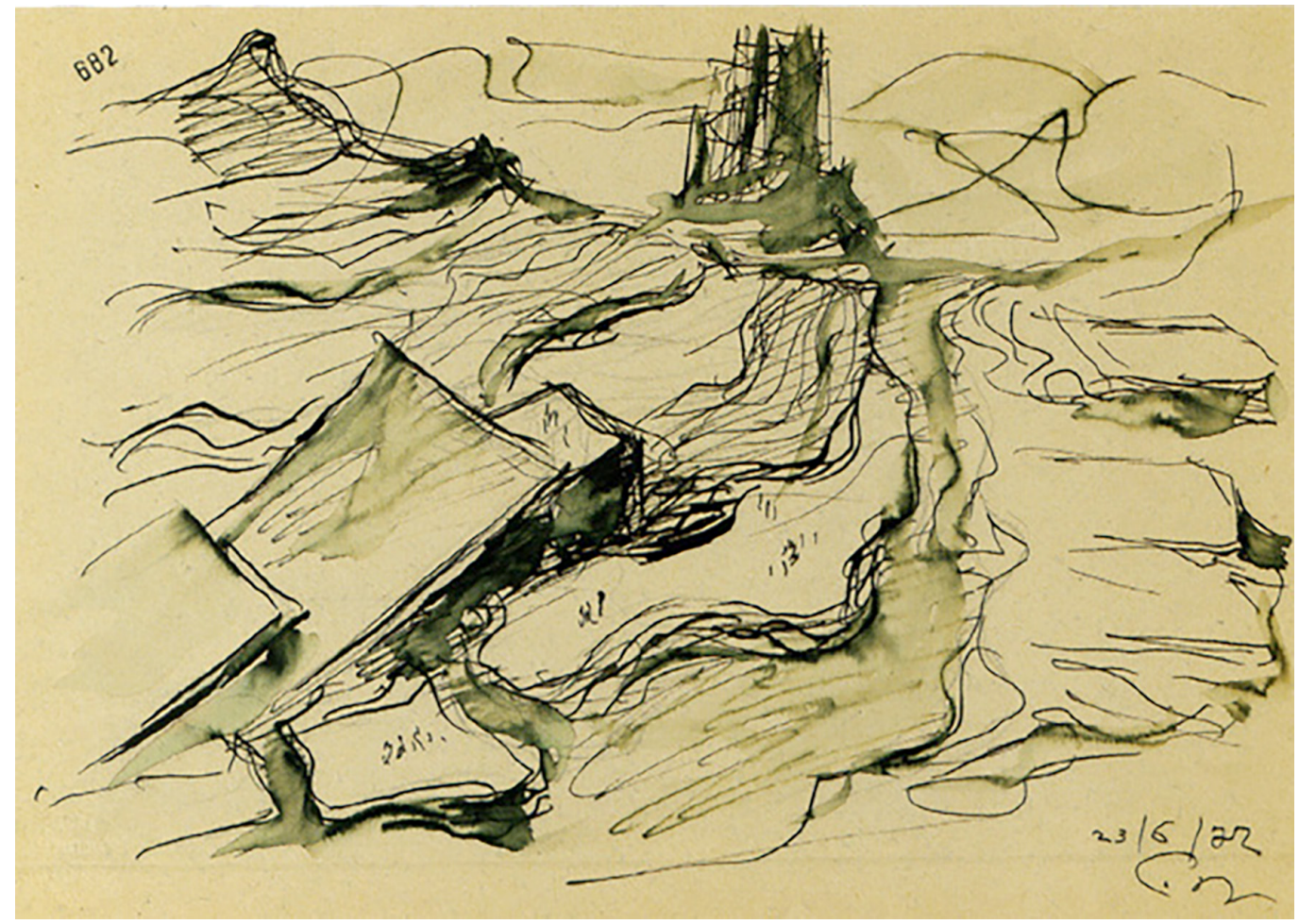

Notes

[ I] Edgar Morin, Puntate sul quoziente emotivo, in: Repubblica 2th April 20 I I <https://ricerca.repubblica.it/repubblica/archivio/ repubblica/20 I I/04/02/puntate-sul-quoziente- emotivo.076.html>

[2] The first version of the interview was published in Perspecta 7 in 196I (pp. 9-28) and was collected in Christian Norberg (1980). Schulz Louis I. Kahn: idea e immagine. 


\section{Riferimenti bibliografici}

Cohen Jean-Louis, (1994). Ludwig Mies van der Rohe. Roma-Bari: Laterza.

Detienne Marcel,Vernant Jean-Pierre (1978). Le astuzie dell'intelligenza nell'antica Grecia. Roma-Bari: Laterza.

Empson William (1965). Sette tipi di ambiguità. Torino: Einaudi.

Gombrich Ernst H. (1965). Arte e illusione. Studio sulla psicologia della rappresentazione pittorica.Torino: Einaudi.

Gregory Richard (1986). L'occhio confuso. In XY dimensioni del disegno, n. I, pp. 19-20. Roma: Cedis Editrice.

Norberg-Schulz Chistian (1980) Louis I. Kahn. Idea e immagine. Roma: Officina Edizioni.

Maciocco Giovanni,Tagliagambe Silvano (1997). La città possibile: territorialità e comunicazione nel progetto urbano. Bari: Dedalo Mérö László (2005). I limiti della razionalità. Intuizione, logica e trance-logica. Bari: Dedalo.

Morin Edgar (20 I I, Aprile 2), Puntate sul quoziente emotivo. In: Repubblica. Estratto da: https://ricerca.repubblica.it/repubblica/ archivio/repubblica/20 I I/04/02/puntate-sul-quoziente- emotivo.076.html.

Samples Bob (1976). The metaphoric mind: A celebration of creative consciousness. Boston: Addison Wesley Publishing Company.

\section{Author}

Michele Valentino, Università degli Studi di Sassari, mvalentino@uniss.it

To cite this chapter:Valentino Michele (2020). Disegno ambiguo e sagace/Ambigous and sagace drawing. In Arena A., Arena M., Brandolino R.G., Colistra D., Ginex G., Mediati D., Nucifora S., Raffa P. (a cura di). Connettere. Un disegno per annodare e tessere. Atti del $42^{\circ}$ Convegno Internazionale dei Docenti delle Discipline della Rappresentazione/Connecting. Drawing for weaving relationships. Proceedings of the 42th International Conference of Representation Disciplines Teachers. Milano: FrancoAngeli, pp. | 434-1449. 